\title{
THE RIGHT TO CHALLENGE WITNESSES - AN APPLICATION OF STRASBOURG'S FLEXIBLE 'SOLE AND DECISIVE’ RULE TO OTHER HUMAN RIGHTS
}

\author{
Elmar Widder ${ }^{*}$
}

\begin{abstract}
The ECtHR's Grand Chamber judgment in the case of Al-Khawaja and Tahery initiated a tremendous amount of literature appertaining to the question of the extent to which the accused's right to confrontation can be limited. A large number of scholars commented on the implications for the rights of the accused, including recommendations that the Court should focus more on the underlying principles for the restriction of this right. This article will leave the latter questions aside and concentrate on a more practical issue by comparing the doctrinal nuances of Strasbourg's Grand Chamber judgment-which are regarded as a convergence of common and civil law traditions-with cases in other regional human rights jurisdictions, i.e. the UN Human Rights Committee and the Inter-American Court of Human Rights. Is the right to confrontation restricted more, or perhaps less, in other jurisdictions and is there a clear line? This article provides the reader with the necessary background information on the new doctrinal elements on the restrictions of the right to confrontation, which have been established by Strasbourg's Grand Chamber. It then uses these elements such as 'necessity' and 'counterbalance' and scrutinises cases of other human rights jurisdictions under these lenses. The results will show whether or not other human rights bodies would have decided differently if they had used the ECtHR's yardstick for their decisions.
\end{abstract}

\section{Keywords}

Fair trial, confrontation, right to have witnesses examined, counterbalance, corroboration of evidence

\section{Introduction}

The volume of literature apropos the extent to which an accused's right to confrontation can be limited, has been augmented and exacerbated ${ }^{1}$ following

* PhD Candidate, University of Hull.

1 See e.g., Laura Hoyano, 'What Is Balanced on the Scales of Justice? In Search of the Essence of the Right to a Fair Trial' (2014) 1 Crim LR 4; Liz Heffernan, 'Hearsay in Criminal Trials: The Strasbourg Perspective' (2013) 49 Irish Jurist 132; Jane Elliott-Kelly, 'Case Comment: Al-Khawaja and Tahery v United Kingdom' (2012) 1 EHRLR 81; Antje Du Bois-Pedain, 'Artikel 6 Abs. 3

Copyright $\odot$ the Author(s).

This work is licensed under a Creative Commons Attribution-NonCommercial-NoDerivs 3.0 License. 
the judgment of the Grand Chamber in Al-Khawaja and Tahery $v$ UK. ${ }^{2}$ Before this verdict was delivered, the so-called 'sole and decisive' rule was previously thought of as a safeguard for the accused, making a conviction impossible in cases where an uncontested statement was the 'sole or the decisive' piece of evidence for a conviction. Scholarship recommended that the European Court of Human Rights $(E C t H R)$ 'engage more with the principles underlying the rights of the defence in order to provide a more coherent basis for [...] the right to challenge witness evidence. ${ }^{3}$ This article, however, will leave these underlying principles aside, apart from the paragraph about the implications, and focus on more practical matters. Stimulated by global communication, the area of evidence and proof has developed norms of 'increasing generality in theory and in practice'; ${ }^{4}$ therefore, this paper is intended to review the possible outcomes of applying the flexible 'sole and decisive' rule to other human rights jurisdictions. To this end, it is necessary to regard the decision of the Grand Chamber in Al-Khawaja and Tahery $v$ UK (Al-Khawaja [GC]) as the convergence of law and practice between the adversarial and inquisitorial procedure, providing a formula for the practical application of the right to challenge witnesses. Before this practical application can take place, however, it is first necessary to explore where the UN Human Rights Committee and Inter-American Court of Human Rights have drawn their lines on confrontation. Only then can the ECtHR's new formula be applied to the facts of the other human rights jurisdictions. Finally, there will be a conclusion as to whether the results in other jurisdictions would look vastly different if Al-Khawaja [GC] were applied. In other words, this article considers the limitations of the right to confrontation by using the flexible 'sole and decisive' rule-established in Al-Khawaja [GC] - as a yardstick against which to measure cases outside the Council of Europe's jurisdiction, in particular, the UN Human Rights Committee and the Inter-American Court of Human Rights. The outcome demonstrates whether other human rights bodies would have decided in a different way if they had used Strasbourg's yardstick to arrive at their decisions. First of all, however, the reader needs to be provided

lit. d EMRK und der nicht verfügbare Zeuge: Weist der modifizierte Lucà-Test den Weg aus der Sackgasse?' (2012) 3 Onlinezeitschrift für Höchstrichterliche Rechtsprechung zum Strafrecht $120<$ http://www.hrr-strafrecht.de/hrr/archiv/12-03/index.php?sz=8> [accessed 12 December 2015].

2 Al-Khawaja and Tahery v UK [2011] ECtHR App Nos 26766/05 \& 22228/06 [GC].

${ }^{3}$ John D Jackson \& Sarah J Summers, The Internationalisation of Criminal Evidence: Beyond the Common Law and Civil Law Traditions (2012) 366.

4 Ibid, 387, citing Johannes F Nijboer, 'Current Issues in Evidence and Procedure - Comparative Comments from a Continental Perspective' (2009) 6 International Commentary on Evidence. 
with a sound introduction to the case history of Al-Khawaja [GC].

\section{Background information}

Surrounded by political tensions, the UK Supreme Court had declined to follow Strasbourg's first judgment of $2009,{ }^{5}$ in which the ECtHR required a strict application of the 'sole and decisive' rule. The UK's answer to the first Al-Khawaja and Tahery judgment was expressed in $R v$ Horncastle. ${ }^{6}$ Therefore, the case of Al-Khawaja and Tahery finally ended up at the Grand Chamber. On reflection and with regard to Imad Al-Khawaja, the Grand Chamber concluded that the strong corroborative evidence of the victim's (ST) friends (BF and $\mathrm{SH}$ ) was accepted as a counterbalancing factor. ${ }^{7}$ More importantly, there was a further statement of another complainant: VU. This witness described the alleged assault very similarly and thus played a major role. Having previously been rejected as corroborative evidence in the first judgment, the Grand Chamber took VU's statement into consideration as a counterbalancing factor. ${ }^{8}$ The latter was probably the significant difference when compared to Mr Tahery's complaint. In Tahery's case, there was no corroborative evidence which could have counterbalanced the restriction to confrontation. According to the Grand Chamber, the 'defence was not able to call any other witness to contradict the testimony provided in the hearsay statement.'

As a result, the ECtHR has finally overthrown its strict interpretation of the 'sole and decisive' rule rather than applying it inflexibly. The reasoning of Strasbourg was that it had to consider the procedures as a whole or, to use the terminology of Al-Khawaja [GC], that it was necessary to carry out an overall assessment of the case. ${ }^{10}$ Put differently, the long history of a strict application of the 'sole and decisive' rule ${ }^{11}$ has now been transformed into a more flexible rule and the so-called minimum standard of Article 6(3)(d) is not an absolute anymore-although it still must be considered as a strong safeguard. Whilst scrutinising the safeguards to ensure fairness and the right to confrontation,

\footnotetext{
5 Al-Khawaja and Tahery $v$ UK [2009] ECtHR Nos 26766/05 \& 22228/06.

${ }^{6} R v$ Horncastle [2010] 2 AC 373.

7 Al-Khawaja and Tahery v UK [2011] ECtHR Nos 26766/05 \& 22228/06 (GC), para 156.

8 Ibid.

9 Ibid, para 162.

${ }^{10}$ Ibid, para 118.

${ }^{11}$ See e.g. Isgrò v Italy (1991) ECHR Ser A No 192; Doorson v The Netherlands (1996) ECHR Ser A No 501; Lucà v Italy [2001] ECtHR App No 33354/96; A L v Finland [2009] ECtHR App No 23220/04.
} 
the Grand Chamber required the application of the three key terms: 'necessity', 'sole or decisive' and 'counterbalance.' ${ }^{\prime 2}$ These keywords were considered as an algorithm of three levels in order to provide a fair outcome for cases in which the witness could not testify in court.

Regarding 'necessity', it is still the general rule that all evidence must be produced in the presence of the accused 'at a public hearing with a view to adversarial argument. ${ }^{13}$ Hence, every evaluation as to the admission of a witness statement which cannot be confronted at trial should be carried out with utmost care. National courts are advised not to be tempted to grant these exceptions too easily. The justification for the non-attendance of a witness at trial requires a narrow interpretation based on the specific reason for the witness' absence. An assessment as to the grounds of the absence, such as death or fear, is thus indispensable.

The significance of the evidence, i.e. whether it is regarded as 'sole or decisive' represents the second step in the assessment of whether or not the restriction of the right to confrontation was lawful. The Grand Chamber still pleads for a procedure of the most searching scrutiny where a conviction is 'based solely or decisively on the evidence of absent witnesses. ${ }^{14}$ As regards to the definitions of 'sole and decisive', it can be held that 'sole' should be used in the sense of the 'only evidence against an accused', whereas 'decisive'-in the context of the Convention-'should be narrowly understood as indicating evidence of such significance or importance as is likely to be determinative of the outcome of the case. ${ }^{15}$ In addition, the test requires an examination of whether or not the chances of a conviction would recede and whether an acquittal advances without the evidence. ${ }^{16}$

If evidence has been considered as 'sole or decisive', the last question would be whether or not there are sufficient factors to counterbalance the detriment to the defence. Counterbalancing factors can be corroborative statements which are not subject to any collusion. Again, the dichotomy lies in the assessment

${ }_{12}$ Al-Khawaja and Tahery $v$ UK [2011] ECtHR Nos 26766/05 \& 22228/06 (GC), para 152.

${ }^{13}$ Ibid, para 118.

${ }^{14}$ Ibid, para 147.

${ }^{15}$ Ibid, para 131. The exact wording of the Grand Chamber reads as follows: "[t]he word "decisive" should be narrowly understood as indicating evidence of such significance or importance as is likely to be determinative of the outcome of the case. Where the untested evidence of a witness is supported by other corroborative evidence, the assessment of whether it is decisive will depend on the strength of the supportive evidence; the stronger the corroborative evidence, the less likely that the evidence of the absent witness will be treated as decisive.'

${ }^{16}$ Ibid. 
of the uncontested statement and the supporting evidence. Remember, the supporting evidence still needs to be sufficient to counterbalance the restriction of the confrontation at the third level of the assessment. Not every case may be as clear-cut as in Al-Khawaja [GC]. Hence, counterbalancing factors include a 'fair and proper assessment of the reliability' of, for example, corroborative statements. ${ }^{17}$ The judges' obligation to warn the jury of the dangers when relying on such statements is probably a lesser factor in the test. As one could see in the Grand Chamber judgment, it was generously overlooked in Al-Khawaja's case, whereas, in Mr Tahery's it did not serve as a sufficient counterbalance at all. ${ }^{18}$

Defence counsel in the métier of criminal law may disagree with the ECtHR's Grand Chamber judgment. On the other hand, it does not give a carte blanche to restrict the right to confrontation endlessly without serious reasons. How this new application of the test would look in other jurisdictions is set out in the following paragraphs.

\section{The UN Human Rights Committee}

The right to confrontation is embedded in Article 14(3)(e) of the ICCPR and its wording is similar to that of the European Convention. As in the developing jurisprudence of the ECtHR, the UN Human Rights Committee $(H R C)$ faced questions regarding the 'necessity' of restricting the right to confrontation, particularly when witnesses were absent. Furthermore, the HRC also saw the need to place an obligation on state parties to prove their efforts in providing defendants with an opportunity to confront witnesses. In addition to the cases in which grave violations against the right to confrontation and other fair trial requirements took place, as for example in Toshev $v$ Tajikistan, ${ }^{19}$ the Committee also dealt with Communications from which one can draw parallels with ECtHR cases.

What is understood as the so-called 'necessity' to restrict in Strasbourg played a major role in Dugin v Russian Federation. In this Communication, the national

\footnotetext{
${ }^{17}$ Ibid, para 147.

${ }^{18}$ Ibid, para 164.

${ }^{19}$ Human Rights Committee, Views: Communication No 1499/2006, $101^{\text {st }}$ sess, UN Doc CCPR/C/101/D/1499/2006 (30 March 2011) 9, para 6.6 (Toshev v Tajikistan): 'the court has failed to ensure the presence and the questioning of important witnesses; [...] Mr Iskandarov was kept unlawfully isolated at the premises of the Ministry of Security and confessed guilt under threats of physical reprisals there, in the absence of a lawyer, and that his complaints on this subject were disregarded'.
} 
courts gave 'very considerable weight' to the statement of a key witness who was not subject to examination at trial. ${ }^{20}$ The state party, however, could not prove its efforts to summon this witness for the trial procedures. ${ }^{21}$ As a result, the HRC was not provided with a plausible explanation as to why it was necessary to restrict the accused's right to examine witnesses and thus concluded that there was a violation. ${ }^{22}$ Interestingly, even if the Human Rights Committee did not mention the term 'necessity' explicitly, there are some visible similarities in comparison to Strasbourg's case law concerning the efforts of state parties that are required to guarantee the right to confrontation.

A further case in which the state party did not prove a necessary restriction as to why the complainant was not allowed to question a key witness is Koreba $v$ Belarus. In this case, the applicant was not allowed to be present at the proceedings whilst one of the prosecution's main witnesses was testifying. The HRC decided on a clear breach of equality of arms in the sense of Article 14(3)(e), stressing the importance of 'ensuring an effective defence ${ }^{23}$ in guaranteeing that the accused and his counsel could cross-examine the prosecution's witnesses. Furthermore, the defence should be given 'the same legal power of compelling the attendance of witnesses relevant for the defence' as are available to the prosecution. ${ }^{24}$ The latter was confirmed in Litvin $v$ Ukraine, a case in which the complainant's son was denied the opportunity 'to call and examine several important witnesses that testified during the preliminary investigation and confirmed, inter alia, his alibi. ${ }^{25}$ In a similar vein, one could also mention the case of Larrañaga $v$ Philippines, ${ }^{26}$ a case in which a judge cut short the defence's cross-examination of the main prosecution witness ${ }^{27}$ and refused to hear the remaining defence witnesses. As one would have expected, the Committee finally concluded on a violation of Article 14(3)(e).

\footnotetext{
${ }^{20}$ Human Rights Committee, Views: Communication No $815 / 1998$, $81^{\text {st }}$ sess, UN Doc CCPR/C/81/D/815/1998 (5 July 2004) para 9.3 (Dugin v Russian Federation).

${ }^{21}$ Ibid: "[w]hile efforts to locate Chikin [the witness] proved to be ineffective for reasons not explained by the State party'.

${ }^{22}$ Ibid.

${ }^{23}$ Human Rights Committee, Views: Communication No 1390/2005, $100^{\text {th }}$ sess, UN DOC CCPR/C/100/D/1390/2005 (25 October 2010) 8, para 7.5 (Koreba v Belarus).

${ }^{24}$ Ibid.

${ }^{25}$ Human Rights Committee, Views: Communication No $1535 / 2006,102^{\text {nd }}$ sess, UN Doc CCPR/C/102/D/1535/2006 (19 July 2011) 14, para 10.4 (Litvin v Ukraine).

${ }^{26}$ Human Rights Committee, Views: Communication No $1421 / 2005$, $87^{\text {th }}$ sess, UN Doc CCPR/C/87/D/1421/2005 (24 July 2006) (Larrañaga v Philippines).

${ }^{27}$ Ibid, para 2.5 .
} 
Having proved that there is a certain requirement for 'necessity' at the HRC, the article will now render a comparison between the HRC's Communication of Rouse $v$ Philippines and the ECtHR's case of Al-Khawaja [GC]. Indeed, the case of Rouse $v$ Philippines seems to be made for the purposes of this article. Besides the questions about the arbitrariness of admitting evidence within national courts, this case also touched upon the issue of restricting the right to confrontation, particularly relating to Strasbourg's 'sole and decisive' rule. The applicant was accused of alleged sexual relations with an under-aged male referred to in the case as GD. The alleged victim, who was the sole eyewitness of the alleged crime, did not testify in court. The HRC finally saw a violation of the applicant's right to confrontation because 'considerable weight was given to that witness' out of court statement $^{28}$ and the accused had no opportunity to cross-examine the alleged victim. Considering the fact that the evidence in this case was 'sole or decisive' and following the flexible interpretation of the Lucà test ${ }^{29}$ one might even think that a lawful conviction could have been possible on first sight. Indeed, there are similarities between Al-Khawaja [GC] and Rouse v Philippines; for example, in both cases the key witnesses were not subject to cross-examination, neither at pretrial nor at the trial stage. Furthermore, supporting statements of other witnesses were available in both cases. Yet, there are differences related to the so-called 'necessity' and 'counterbalance' between the two cases.

Firstly, there could be concern as to the diligence of the state party in securing the alleged victim's appearance at court in the case of Rouse $v$ Philippines. Admittedly, there are cases in which witnesses cannot be located but in the present case, however, the government did not give any explanations as to how it tried to locate the alleged victim or his parents. Hence, one of the questions could be: were the grounds for the non-appearance of the witness really unavoidable? ${ }^{30}$ In the example of Al-Khawaja [GC], this question was irrelevant: the witness had died before the trial started, thus her appearance was factually impossible.

Secondly, in Rouse $v$ Philippines as in Al-Khawaja [GC], a third party gave a witness statement alleging a similar criminal allegation concerning the accused as to the present one. In the case of Rouse, it was a young adult who affirmed that he had engaged in sexual activities with the accused one day before the accused's arrest. The difference, however, rests on what has been confirmed in the two cases: in Rouse $v$ Philippines, the third party giving the statement could not shed

\footnotetext{
${ }^{28}$ Human Rights Committee, Views: Communication No 1089/2002, $84^{\text {th }}$ sess, UN Doc CCPR/C/87/D/1089/2002 (25 July 2005) para 7.5 ('Rouse v Philippines').

${ }^{29}$ Lucà v Italy [2001] ECtHR App No 33354/96.

${ }^{30}$ The Criminal Justice Act 2003 (UK), for example, requires such an element in s 116(2)(d).
} 
any light on the accusations against the applicant. The accused was charged with child abuse but the witness giving the statement was an adult. The court's finding that the third party witness 'looks like a minor ${ }^{31}$ may be an indication but cannot be regarded as a fact. On the other hand, in the case of Al-Khawaja [GC], the witness VU made descriptions of another alleged assault with strong similarities. Hence, the strength of the corroborative evidence in Al-Khawaja [GC] was far more applicable to support the accusation than it was in the case of Rouse. In addition, all of the persons providing supportive evidence were subject to cross-examination in Al-Khawaja [GC] which was, on the contrary, not the case in Rouse. Notwithstanding the turmoil regarding the admissibility of evidence which may be considered peripheral to the body of the trial in Rouse, one can see that the new, more flexible doctrine applied by Strasbourg would have led to the same outcome in Rouse, even though at the time the HRC's reasoning was more focused on the weight of the out of court statement. ${ }^{32}$

\subsection{Evaluation}

There are parallels to be drawn between the cases of the HRC and the ECtHR. Both institutions stressed the need for diligence on the part of state parties to ensure the presence of key witnesses at trial. In cases of impossibility, whether factual or legal, both institutions tried to measure the influence of hearsay statements with the outcome. Whereas Strasbourg named it the 'sole and decisive' rule, the HRC described it as 'considerable weight was given to [...] [an] out of court statement'. ${ }^{33}$ The interesting point here is that the HRC's approach and the approach taken by Strasbourg do not contradict each other, regardless of whether or not the Lucà test is applied flexibly or inflexibly. The comparative illustration of Al-Khawaja [GC] with Rouse shows that the conclusions would be identical. As a result, it can be held that there is an element of convergence between the two institutions in the area of the right to confrontation and its limits.

\section{The Inter-American Court of Human Rights}

In the American Convention, the right to confrontation can be found in Article $8(2)(f)$. It is regarded as one of the due guarantees of the right to a fair trial and

\footnotetext{
${ }^{31}$ Rouse $v$ The Philippines, UN Doc CCPR/C/87/D/1089/2002, para 2.10.

${ }_{32}^{32}$ Ibid, para 7.5 .

33 Ibid.
} 
ensures the examination of witnesses present in court. It is, however, not absolute and certain restrictions might apply. There may be situations in which the lives of witnesses or the judiciary are endangered, and consequently there may be limitations to the right to confrontation. One of the most widespread examples is when the defendant himself, or those acting on his behalf, intimidate witnesses in order to escape conviction. In such a situation, his or her rights to confrontation should be waived, as was confirmed in Strasbourg's case of Al-Khawaja [GC]. ${ }^{34}$

To this end, the Inter-American Commission on Human Rights (IACmHR) determined some 'ineffectiveness of criminal proceedings ${ }^{35}$ when ' $t$ ] hose responsible for human rights abuses sometimes ensure their impunity by threatening or attacking those who might contribute to a sanction against them. ${ }^{36}$ Nonetheless, the latter should not automatically lead to 'faceless" justice systems, ${ }^{37}$ id est anonymous witnesses, which would, in turn, threaten the basic idea of 'adequate due process guarantees.' ${ }^{38}$ In its report on the domestic situation in Colombia, the IACmHR had to deal with exactly such a dichotomy and 'expresse[d] its most serious concern regarding the lack of due process rights for defendants ${ }^{39}$ if Colombia did not 'take all measures necessary to ensure the safety of witnesses. ${ }^{40}$ In some cases, for instance, one witness provided incriminating evidence under several code names which led judges to believe that different witnesses had testified similar facts and, as a result, corroborated one another's testimony. ${ }^{41}$ Such a development is, of course, unacceptable.

Returning to one of the crucial points of this article, namely the assessment of cases with the flexible Lucà test as a meter, it can be held that there is a general agreement to restrict the right to confrontation, especially when the interests of witnesses or victims are at stake. ${ }^{42}$ The IACmHR pointed out that it was important to grant the witnesses' anonymity in such cases, 'without compromising a defendant's fair trial rights. ${ }^{43}$ Hence, the Commission established similar prerequisites such as 'necessity' and 'counterbalance'. Regarding anonymous witnesses, for

\footnotetext{
${ }^{34}$ Al-Khawaja and Tahery v UK [2011] ECtHR Nos 26766/05 \& 22228/06 (GC), para 123.

${ }^{35}$ IACmHR, Third Report on the Human Rights Situation in Colombia (26 February 1999) Chapter V, para 67.

${ }^{36}$ Ibid.

${ }^{37}$ Ibid, para 121.

38 Ibid.

${ }^{39}$ Ibid, para 127.

${ }^{40}$ Ibid, Recommendation 5.

${ }^{41}$ Ibid, para 125.

${ }^{42}$ IACmHR, Report on Terrorism and Human Rights (22 October 2002) para 251.

${ }^{43}$ Ibid.
} 
example, one could interpret the Commission's description of 'necessity' as the 'sufficiency of the grounds for maintaining a particular witness's anonymity', ${ }^{4}$ including the reliability of their statements. Furthermore, the IACmHRreferred to the European case of Doorson ${ }^{45}$ which concerned the 'sole and decisive' rule in cases where witnesses testified anonymously. In the latter case, the Strasbourg court stressed the importance of judges being aware of the identity of those anonymous witnesses and that it was crucial for the defence to challenge the evidence of these witnesses, even if the applicants did not know their identity. ${ }^{46}$ The most significant similarity, however, is that the Inter-American Commission used a similar wording ${ }^{47}$ to underline what has been called the 'sole and decisive' rule in Strasbourg and which had been rigorously applied until Al-Khawaja [GC]. The lack of recent case law within the area of the Inter-American Court may leave a little gap with regard to the latest interpretation of the 'sole and decisive' rule which has now become more flexible at the ECtHR. On the other hand, the Commission Report on Terrorism clearly shows a basic conformity of the application of the right to confrontation. As a result, one can determine that Strasbourg's case law may be more explicit. The fundamental structures of the two jurisdictions, however, remain similar.

\subsection{Evaluation}

In all three jurisdictions, ECtHR, HRC and the Inter-American institutions, there is common agreement that, in some cases, a restriction of the right to confrontation is not incompatible with the right to a fair trial per se. Furthermore, the assessment of the right to confrontation has revealed that the new flexible interpretation of the ECtHR's 'sole and decisive' rule does not contradict the cases of the Inter-American Court of Human Rights; although the latter does not provide us with similar cases on which the yardstick of Al-Khawaja [GC] can be applied. As a result, the basic framework of Strasbourg and San José regarding confrontation rest in the same intersection, however there are no conclusions as clear cut as in the previous assessment of the Human Rights Committee in Rouse $v$ Philippines.

\footnotetext{
${ }^{44}$ Ibid.

${ }^{45}$ Doorson $v$ The Netherlands (1996) ECHR Ser A No 501, paras 66-83.

${ }^{46}$ Ibid.

${ }^{47}$ See IACmHR, Report on Terrorism and Human Rights (22 October 2002) para 251: 'and the significance of the evidence in the case against the defendant, in particular whether a conviction may be based solely or to a decisive extent on that evidence'.
} 


\section{Theoretical and practical implications}

The idea of a flexible interpretation of the 'sole and decisive' rule also raised questions about 'fairness'. Ronald Dworkin's thoughts on evidence and procedure suggest that a criminal trial needs to be 'decided by striking "the right balance" between the interests of the individual and the interests of the community as a whole. ${ }^{48}$ If a procedure leads to a conviction of the innocent and an acquittal of the guilty, the individual will suffer from what Dworkin calls 'moral harm. ${ }^{49}$ In order to avoid this 'moral harm', which is to be distinguished from 'bare harm, ${ }^{50}$ the accused is said to have two genuine rights: first, he or she is entitled to the right that a majority of the society establishes a trial procedure which puts a 'proper valuation on moral harm in the calculations that fix the risk of injustice. ${ }^{51}$ Second, however high this level may be, it needs to be applied equally. Dworkin describes it as a procedure which holds the community to a 'consistent enforcement of its theory of moral harm' ${ }^{52}$ Each of the latter two rights may act as a trump over the balance between the gains of society or the individual and hence, a middle ground emerges. This middle ground is the terrain in the centre of two radical edges: one consists of a complete denial of procedural rights (supreme accuracy), and the other promotes procedural rights.

The judgment of Al-Khawaja [GC] was a definitive shift towards more accuracy rather than promoting procedural rights. Moreover, it is probably fair to mention that Al-Khawaja [GC] contains some inconsistencies, which have not necessarily clarified the issues of restricting the right to confrontation. Having read the judgment, one still awaits the answer as to why Strasbourg deemed it necessary to allow a flexible application of the 'sole and decisive' rule. As Liz Heffernan comments, a breach of the so-called minimum right of Article 6(3)(d) does 'not invariably undermine the fairness of the trial. ${ }^{53}$ But does the Court explain why such a limitation may be justified? Not necessarily. The dissenting opinions of judges Sajó and Karakaş express the conflict of interest in more detail. As they describe it, the issue at stake is 'the relationship between

\footnotetext{
${ }^{48}$ Ronald Dworkin, A Matter of Principle (1985) 73.

${ }^{49} \mathrm{Ibid}, 80$; Dworkin regards moral harm also as the 'injustice factor'.

${ }^{50}$ Ibid: 'bare harm' is the harm 'a person suffers through punishment, whether that punishment is just or unjust-for example, the suffering or frustration or pain or dissatisfaction of desires that he suffers just because he loses his liberty or is beaten or killed-and the further injury that he might be said to suffer whenever his punishment is unjust, just in virtue of that injustice'.

${ }^{51}$ Ibid 92.

${ }^{52}$ Ibid 90.

${ }^{53}$ Heffernan, above n 1, 140.
} 
the fundamental human rights of the accused and society's legitimate interest in imposing punishment-after a fair trial. ${ }^{54}$ The important question for them seems to be whether the counterbalancing factors of the flexible 'sole and decisive' rule can 'absorb or undermine specific individual rights which are defined in the Convention'. ${ }^{55}$ According to the judges, in the administration of justice, the right to confrontation was fundamental to guarantee the fair trial and balancing these rights - as had been done in Al-Khawaja [GC] - would give the prosecution 'a clear advantage' ${ }^{56}$ Furthermore, the judges criticise the absence of a clear explanation as to how 'fairness can still be achieved if one of the fundamental rights is deprived of its essence. 57

While the judges plead for a clear line and vote in favour of an inflexible application of the 'sole and decisive' rule, the author is not necessarily against its flexible application. It would, however, be more than useful for the ECtHR to explain why such a flexible approach is regarded as helpful and finally, why it can enhance the fairness of trial proceedings. Whilst the argument for excluding unreliable evidence appears to be stable, one must, on the other hand, also admit the argument for the exclusion of probative evidence in case the 'sole and decisive' rule is strictly applied. An out-of-court statement may depict important and probative evidence which would automatically be excluded in cases where the witness had died before the trial and would not be subject to confrontation. The most popular and dramatic example is the dying victim telling the police officer the name of the murderer in the very last moments before passing away.

Establishing the truth is a reasonable goal which should be, or at least try to be, achieved. ${ }^{58}$ However, establishing the truth at the expense of minimum human rights raises questions as to whether this is the method for reaching fairness in a trial. Whilst the legal rhetoric decides whether a defendant should, under certain circumstances, accept limitations to confrontation, one needs to bear in mind what the purpose of minimum human rights is. In the dissenting opinions of Judges Sajó and Karakaş, minimum rights are described as equalling the imbalance between the state and the citizen. ${ }^{59}$ Generally, everybody desires

\footnotetext{
${ }^{54}$ Al-Khawaja and Tahery v UK [2011] ECtHR Nos 26766/05 \& 22228/06 (GC) (Sajó and Karakaş $\mathrm{JJ})$.

55 Ibid.

56 Ibid.

${ }^{57}$ Ibid.

${ }^{58}$ It is agreed that there are epistemological difficulties to find out the exact truth in a trial.

${ }^{59}$ Al-Khawaja and Tahery v UK [2011] ECtHR Nos 26766/05 \& 22228/06 (GC) (Sajó and Karakaş $\mathrm{JJ})$.
} 
the principal objective of a criminal process to be the acquittal of the innocent and the conviction of the guilty. ${ }^{60}$

To conclude, the author can indeed understand the concerns of Judges Sajó and Karakaş as well as Judge Richardson warning words quoted by Lord Bingham. ${ }^{61}$ Furthermore, it is agreed that both in the interests of justice and in order to detect and prosecute crime, society should never agree to a position where witnesses can be absent at trial and enjoy anonymity at the same time. In any case, the right to confrontation should serve as a definitive guarantor to protect against a defendant's wrongful conviction; yet it should not bar the accused from a deserved penalty. In 2011, Professor Damaška indicated that '[t]he accuracy of factual determinations' was no longer a high priority, at least not in legal scholarship on the European continent. ${ }^{62}$ According to him, procedural justice had gained at the expense of its antipode 'accuracy'. Imagining procedural rights as a road, and accuracy as the destination, Damaška described the situation as follows: "[t]he road to the destination seems to be becoming more important than the increasingly uncertain destination itself.' ${ }^{63}$ The Grand Chamber judgment of Al-Khawaja reversed this trend, and the flexible 'sole and decisive rule' brings 'accuracy' back into play. Finally, it is up to society to choose either to grant minimum standards and acknowledge misuse in certain cases or, to aim for a strict and narrow procedure based on impartial and unbiased thinking, which needs to be given some flexibility in the most difficult cases.

\section{Conclusion}

Various parallels can be drawn between the cases of the European Court of $\mathrm{Hu}-$ man Rights, the Human Rights Committee and the Inter-American institutions. All three jurisdictions stress the need for diligence on behalf of state parties to ensure the presence of key witnesses at trial but also the protection of witnesses under certain circumstances. As regards Strasbourg's flexible application of the Lucà test in comparison to the HRC's case of Rouse v Philippines, it can be held that the comparison revealed a similar outcome. In terms of the ECtHR's flexi-

\footnotetext{
${ }^{60} R v$ Horncastle [2010] 2 AC 373, 433.

${ }^{61}$ Al-Khawaja and Tahery v UK [2011] ECtHR Nos 26766/05 \& 22228/06 (GC) (Sajó and Karakaş JJ). Richardson J's words in $R v$ Hughes [1986] 2 NZLR 129, 147 are quoted in the dissenting opinion, but can also be found in $R v$ Davis [2008] 1 AC 1128, 1139.

${ }^{62}$ Mirjan Damaška, "The Competing Visions of Fairness: The Basic Choice for International Criminal Tribunals' (2011) 36 NC J of Int'l L \& Comm Reg 365, 369-70.

${ }^{63}$ Ibid, 370.
} 
ble test in comparison with the Inter-American Court of Human Rights, the two jurisdictions show some basic mirror images, though there was no comparable case in which the arithmetic exercise of the flexible interpretation could be calculated consistently until the end. Therefore, the final result which can be drawn for both institutions, the HRC and the Inter-American institutions, is that they could adopt Strasbourg's doctrine in future cases. So far, there have not been any contradicting results to the new 'sole and decisive' rule established by the ECtHR. Whether or not the HRC and the Inter-American Court are finally willing to follow this approach, however, remains to be seen. 